\title{
The solubility of thorium in carbonate-bearing solutions at hydrothermal conditions
}

\author{
HAYLEA NISBET $^{1}$, ARTACHES MIGDISSOV ${ }^{1}$, ANTHONY \\ WILLIAMS-JONES ${ }^{2}$, VINCENT VAN HINSBERG ${ }^{2}$, \\ HONGWU XU ${ }^{1}$ AND ROBERT ROBACK ${ }^{1}$ \\ ${ }^{1}$ Los Alamos National Laboratory \\ ${ }^{2}$ McGill University \\ Presenting Author: haylea.nisbet@mail.mcgill.ca
}

Thorium mineralization is frequently hosted in carbonatebearing rocks, and thorium commonly substitutes into the structures of carbonate-bearing minerals that have precipitated from or been modified by hydrothermal fluids. Given this common association, it is reasonable to propose that the presence of carbonate ligands in hydrothermal solutions promotes the transport of Th through the formation of stable aqueous complexes. Our ability to evaluate this hypothesis, however, is hindered by the lack of experimental data for Th-carbonate species at conditions beyond ambient. The low-temperature data indicate that carbonate is a strong complexing agent for Th.

In this study, we investigated the solubility of Th in carbonatebearing fluids at elevated temperature $\left(175-250^{\circ} \mathrm{C}\right)$ by the autoclave solubility technique [1]. We demonstrate that, in contrast to its behavior at low temperature, Th does not form stable carbonate complexes at the temperatures investigated. Instead, its solubility is governed by hydrolysis reactions. Under the experimental conditions investigated $(0.05-0.5 \mathrm{~m}$ $\mathrm{NaHCO}_{3} / \mathrm{Na}_{2} \mathrm{CO}_{3} ; \mathrm{pH}_{\mathrm{T}}$ 7.8-9.8), the hydroxyl complexes are $\mathrm{Th}(\mathrm{OH})_{4}{ }^{0}$ and $\mathrm{Th}(\mathrm{OH})_{5}{ }^{-}$. Thermodynamic formation constants were derived for these species at the temperatures considered in our experiments to permit forward modeling of Th mobility in natural systems. Our study concludes that Th-carbonate species are unlikely to play a major role in the transport of Th in natural hydrothermal fluids.

[1] Migdisov et al. (2009) Geochimica et Cosmochimica Acta 73, 7087-7109. 